\title{
PENGARUH STRUKTUR MODAL, NET PROFIT MARGIN, RETURN ON ASSET, DAN RETURN ON EQUITY, TERHADAP NILAI PERUSAHAAN PADA SEKTOR INDUSTRI MAKANAN DAN MINUMAN DI BURSA EFEK INDONESIA
}

\section{NURAPIAH dan NANANG QOSIM}

(Dosen Tetap Yayasan Fakultas Ekonomi Universitas Alkhairaat Palu)

\begin{abstract}
ABSTRAK
Penelitian bertujuan untuk mengetahui pengaruh struktur modal (DER), net profit margin (NPM), return on asset (ROA), dan return on equity (ROE) secara Simultan maupun parsial terhadap nilai perusahaan pada perusahaan makanan dan minuman yang terdaftar di Bursa Efek Indonesia, penelitian diharapkan dapat memberikan masukan dalam membuat kebijakan berhubungan dengan hutang untuk menghasilkan laba perusahaan. Analisis yang digunakan adalah analisis regresi data panel dengan Eviwes 9,5. Jumlah populasi 16 perusahaan dan sampel 11 perusahaan. Berdasarkan hasil penelitian diketahui bahwa nilai probabita variabel DER $\left(\mathrm{X}_{1}\right)=0,863>\alpha$ 0,05; Variabel NPM $\left(\mathrm{X}_{2}\right)=0,082>\alpha$ 0,05; Variabel ROA $\left(\mathrm{X}_{3}\right)=0,989>$ 0,05 ; Variabel $\mathrm{ROE}\left(\mathrm{X}_{4}\right)=0,772>\alpha$ 0,05; secara parsial ke empat variabel independen tidak berpengaruh signifikan terhadap nilai perusahaan pada perusahaan makanan dan minuman yang terdaftar di Bursa Efek Indonesia (BEI). Hasil perhitungan F statistik diperoleh Probabilita 0,004 < $\alpha$ 0,05; Sehingga variabel DER, NPM, ROA dan ROE secara simultan berpengaruh signifikan terhadap nilai perusahaan pada perusahaan makanan dan minuman yang terdaftar di Bursa Efek Indonesia (BEI). nilai koefisien determinasi $\left(\mathrm{R}^{2}\right)$ sebesar 0,199 berarti variabel dependen dipengaruhi oleh variavel independen DER, NPM, ROA dan ROE sebesar 19,9\% sedangkan sisanya 80,1\% dipengaruhi oleh oleh variabel lain.

Kata kunci: Struktur Modal (DER), Net Profit Margin (NPM), Return On Asset (ROA), dan Return On Equity (ROE) dan Nilai Perusahaan.
\end{abstract}

\section{LATAR BELAKANG}

Bursa efek Indonesia (BEI) yang sebelumnya bernama Bursa Efek Jakarta (BEJ) merupakan hasil merger dengan Bursa Efek Surabaya. Sesuai dengan kegiatan usahanya, Bursa Efek Indonesia (BEI) memberikan layanan jasa transaksi efek, jasa pencatatan, dan jasa informasi dan fasilitas lainnya. Jasa transaksi efek adalah jasa yang diberikan untuk pelaksanaan jual dan beli efek. Sedangkan jasa pencatatan adalah jasa pencatatan emiten atas saham dan obligasi. Jasa informasi dan fasilitas lainnya adalah jasa yang memberikan informasi kepada anggota Bursa, Kantor berita, Media massa dan perusahaan serta penyediaan terminal pelaporan transaksi obligasi.

\section{KAJIAN PUSTAKA}

Struktur modal adalah perimbangan jumlah hutang jangka pendek yang bersifat tetap, hutang jangka panjang, saham preferen, dan saham biasa (Halim 2007).

Return On Asset (ROA) menurut Kasmir (2012;201) adalah rasio yang menunjukan hasil
(Return) atas jumlah aktiva yang digunakan dalam perusahaan. Selain itu, ROA memberikan ukuran yang lebih baik atas profitabilitas perusahaan karena menunjukan efektivitas manajemen dalam menggunakan aktiva untuk memperoleh pendapatan.

Return On Asset (ROA) digunakan untuk mengukur efektifitas perusahaan dalam menghasilkan keuntungan dengan memanfaatkan aktiva yang dimilikinya. ROA merupakan rasio antara laba sesudah pajak terhadap total asset. Semakin besar ROA menunjukkan kinerja perusahaan semakin baik, karena tingkat pengembalian (Return) semakin besar. ROA juga merupakan perkalian antara faktor net income margin dengan perputaran aktiva.

Return On Equity (ROE) Menurut Mardiyanto (2009;196) ROE adalah rasio yang digunakan untuk mengukur keberhasilan perusahaan dalam menghasilkan laba bagi para pemegang saham. ROE dianggap sebagai representasi dari kekayaan pemegang saham atau nilai perusahaan. Menurut Riyadi (2006;155) Return On Equity (ROE) adalah perbandingan 
antara laba bersih dengan modal (modal inti) perusahaan.

Menurut (Umar A, 2019) Perusahaan merupakan suatu lembaga yang terdiri dari beberapa orang yang bekerja sama untuk menyediakan barang atau jasa yang dibutuhkan masyarakat. Nilai perusahaan merupakan harga yang bersedia dibayar oleh calon pembeli apabila perusahaan tersebut dijual (Husnan;2009). Nilai perusahaan dalam presepsi investor merupakan tingkat keberhasilan perusahaan yang berhubungan dengan harga sahamnya. Harga saham yang digunakan umumnya mengacu pada harga penentuan (Clossing price), dan merupakan harga yang terjadi pada saat saham diperdagangkan di bursa. Harga saham yang tinggi membuat nilai perusahaan juga tinggi, dan meningkatkan kepercayaan pasar terhadap kinerja perusahaan saat ini dan prospek perusahaan di masa mendatang. Menurut (Marjun, 2019) Setiap perusahaan harus mampu memberikan pelayanan yang terbaik kepada konsumen, hingga akhirnya tercipta kepuasan dari adanya Dimensi Kualitas Layanan tersebut.

\section{METODE PENELITIAN}

Jenis penelitian yang digunakan adalah kuantitatif. Populasi dalam penelitian ini adalah perusahaan Makanan dan Minuman yang terdaftar di Bursa Efek Indonesia (BEI) pada tahun 20122016. Metode penentuan sampel dalam penelitian ini adalah Purposive Sampling. Jenis data yang digunakan dalam penelitian yaitu data sekunder berupa laporan keuangan tahunan pada Indonesian stock exchange (IDX).

Metode analisis yang digunakan dalam penelitian ini adalah analisis regresi linear berganda dengan struktur data panel. Analisis data yang dilakukan dengan bantuan program Eviews sebagai alat untuk meregresikan model yang telah dirumuskan. Data dianalisis secara statistic antara lain data runtut waktu (time series) dan data silang waktu (cross-section) dan data panel yaitu gabungan antara data time series dan crosssection. Data penel sering disebut juga pooled data (pooling time series dan cross-section), micropanel data, longitudinal data, event history analysis, dan cohort analysis.

\section{HASIL PENELITIAN}

\section{Analisis Regresi Data Panel}

Regresi dengan data panel diharuskan memilih beberapa model pendekatan yang paling tepat untuk mengestimasi data panel yaitu pendekatan model Common Effect, model Fixed Effect dan model Random Effect. Penjelasannya adalah sebagai berikut.

\section{Pendekatan Model Common Effect}

Pendekatan dengan model Common Effect merupakan pendekatan yang paling sederhana untuk mengestimasi data panel. Pendekatan dengan model common effect memiliki kelemahan yaitu ketidaksesuaian model dengan keadaan yang sesungguhnya karena adanya asumsi bahwa perilaku antar individu dan kurun waktu sama padahal pada kenyataannya kondisi setiap objek akan saling berbeda pada suatu waktu dengan waktu lainnya (Widarjono;2013).

\section{Pendekatan Model Fixed Effect}

Pendekatan model fixed effect mengasumsikan adanya perbedaan antar objek meskipun menggunakan koefisien regresi yang sama. Fixed effect disini maksudnya adalah bahwa satu objek memiliki konstan yang tetap besarnya untuk berbagai periode waktu, demikian pula dengan koefisien regresinya (Widarjono; 2013

Pendekatan Model Random Effect

Pendekatan model random effect ini adalah mengatasi kelemahan dari model fixed effect. Model ini dikenal juga dengan sebutan model generalized least square (GLS). Model random effect menggunakan residual yang diduga memiliki hubungan antar waktu dan antar objek. Untuk menganalisis data panel menggunakan model ini ada satu syarat yang harus dipenuhi yaitu objek data silang lebih besar dari banyaknya koefisien (Widarjono;2013).

\section{Pemilihan Model Estimasi Regresi Data Pane}

Pengolahan regresi data panel terlebih dahulu harus memilih model estimasi yaitu comment effect, fixed effect dan random effect. Pemilihan model dilakukan dengan uji chow dan uji hausman, penjelasannya adalah sebagai berikut:

\section{Uji Fixed Effect Test}

Uji Fixed Effect Tests merupakan sebuah pengujian untuk memilih antara model common effect dan model fixed effect yang tepat. Fixed effect tests merupakan uji dengan melihat hasil dari signifikansi statistik dari koefisien yang diestimasi dan nilai $\mathrm{R}^{2}$-nya. Apabila nilai $\mathrm{R}^{2}$ dan nilai Durbin Waston lebih tinggi maka Ha tidak di tolak, namun jika nilai $\mathrm{R}^{2}$-nya dan nilai Durbin Waston lebih rendah maka $\mathrm{Ha}$ ditolak. Ha menyatakan bahwa model fixed effect yang lebih baik digunakan dalam mengestimasi data panel 
dan Ho menyatakan bahwa model fixed effect sama dengan model commen effect (Ghozali;2012;269). Berikut ditampilkan hasil output Pendekatan common effect dan fixed effect.

Tabel 1 Hasil Regresi Data Panel dengan Pendekatan Common effect dan Fixed effect

\begin{tabular}{|c|c|c|c|c|}
\hline \multirow[b]{2}{*}{ Variable } & \multicolumn{2}{|c|}{ Common Effect } & \multicolumn{2}{|c|}{ Fixed Effect } \\
\hline & Coefficient & Prob. & Coefficient & Prob. \\
\hline $\mathrm{C}$ & -3.449136 & 0.5122 & -2.769473 & 0.6244 \\
\hline $\mathrm{X} 1$ & 3.364683 & 0.3922 & -0.640828 & 0.8681 \\
\hline $\mathrm{X} 2$ & 66.01643 & 0.1614 & 115.9354 & 0.0629 \\
\hline $\mathrm{X} 3$ & 16.54318 & 0.6400 & -4.637085 & 0.8963 \\
\hline $\mathrm{X} 4$ & -8.374200 & 0.6411 & -3.803043 & 0.8393 \\
\hline R-squared & 0.299598 & \multicolumn{2}{|c|}{ R-squared } & 0.616048 \\
\hline Adjusted R-squared & 0.243566 & \multicolumn{2}{|c|}{ Adjusted R-squared } & 0.481665 \\
\hline Prob (F-statistic) & 0.000000 & \multicolumn{2}{|c|}{ Prob (F-statistic) } & 0.000074 \\
\hline $\begin{array}{l}\text { Durbin-Watson stat } \\
\text { Sumber: output ev }\end{array}$ & 1.21722 & \multicolumn{2}{|c|}{ Durbin-Watson stat } & 2.163280 \\
\hline
\end{tabular}

Tabel 1 Menunjukan hasil regresi menggunakan model pendekatan commen effect dan fixed effect. Hasil regresi dari kedua model tersebut memiliki hasil yang berbeda. Pendekatan fixed effect memiliki r-squared, adjusted r-squared dan durbin-watson stat lebih besar dibandingkan r-squared, adjusted r-squared dan durbin-watson stat dari pendekatan comment effect. Untuk menentukan model yang lebih baik commen effect atau fixed effect harus dilakukan fixed effect test atau uji chow. Kriteria pengambilan keputusannya apabila nilai prob Cross-section $>\boldsymbol{\alpha}=\mathbf{0 , 0 5}$, maka model yang terbaik adalah commen effect sebaliknya jika nilai prob $<\boldsymbol{\alpha}=\mathbf{0 , 0 5}$, maka model yang terbaik adalah fixed effect. Berikut ditampilkan hasil output uji chow. Berikut hasil output uji fixed effect test.

Tabel 2 Uji Fixed Effects Tests

Redundant Fixed Effects Tests

Equation: FIXED

Test cross-section fixed effects

\begin{tabular}{lrrr}
\hline \hline Effects Test & Statistic & d.f. & Prob. \\
\hline \hline & 3.296769 & $(10,40)$ & 0.0034 \\
Cross-section F & 33.062554 & 10 & 0.0003 \\
Cross-section Chi-square & & & \\
\hline \hline
\end{tabular}

Sumber: output eviews 9,5 vs
Hasil output diatas memberikan nilaiF sebesar 3,29 dengan dan signifikan, sehingga dapat disimpulkan model fixed effect lebih baik dibandingkan model common effect.

\section{Uji Hausman}

Uji hausman dilakukan untuk menentukan model yang terbaik fixed effect atau random effect menggunakan statistic chi square dengan degree of freedomadalah sebayak k. Dimana $\mathrm{k}$ adalah jumlah variabel independen, apabila nilai statistic chi square lebih besar dibandingkan tingkat signifikan $\alpha=0,05$, maka Ho ditolak yang artinya model yang lebih baik adalah model random effects. Apabila nilai statisticchi square lebih kecil dari tingkat signifikan $\alpha=0,05$ maka Ho diterima yang artinya model yang lebih baik adalah fixed effects (Widarjono; 2013). Sebelum dilakukan uji hausman berikut ditampilkan hasil output perbandingan model fixed effect dan model random effect.

Tabel 3 Hasil Regresi Data Panel dengan Pendekatan Fixed effect dan Random effect

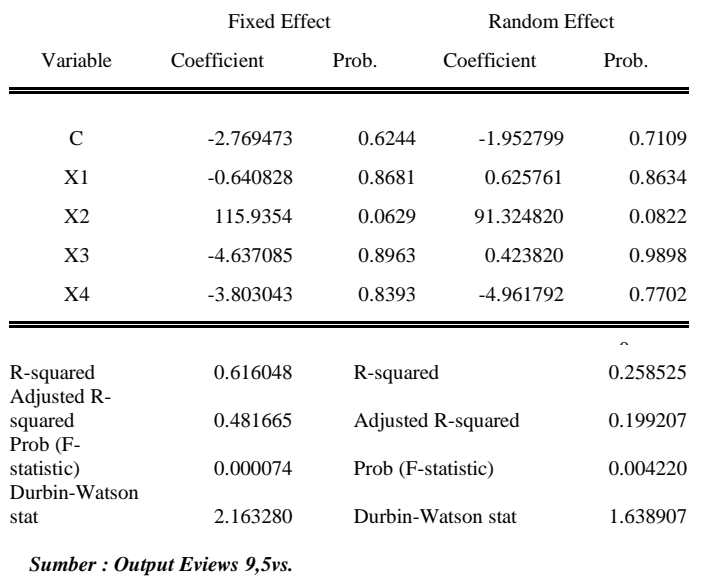

Hasil regresi menggunakan model pendekatan fixed effect dan random effect Hasil regresi dari kedua model tersebut memiliki hasil yang berbeda. Pendekatan fixed effect memiliki rsquared, adjusted r-squareddan durbin-watson stat lebih besar dibandingkan r-squared, adjusted rsquared dan durbin-watson stat dari pendekatan random effect. Untuk menentukan model yang lebih baik fixed effect atau random effect harus dilakukan uji housman. Berikut hasil output uji housman. 
Tabel 4 Uji Hausman

Correlated Random Effects - Hausman Test

Equation: Uji Hausman

Test cross-section random effects

\begin{tabular}{lccc}
\hline \hline \multirow{2}{*}{ Test Summary } & Chi-Sq. Statistic & $\begin{array}{c}\text { Chi-Sq. } \\
\text { d.f. }\end{array}$ & Prob. \\
\hline \hline Cross-section random & 3.773592 & 4 & 0.4375 \\
\hline \hline
\end{tabular}

Sumber : Output Eviews 9,5 sv

Tabel 4 merupakan tabel uji hausman yang menunjukkan prob lebih besar dari tingkat signifikan yang digunakan $0,4375>\alpha=0,05$. Maka model regresi data panel yang paling sesuai dalam penelitian ini menggunakan model Random effect.

Berdasarkan pengujian diatas diperoleh persamaan regresi data panel dengan model Random effect sebagai berikut.

$$
\begin{gathered}
Y=-1.952799+0,625761 X_{1}+91,32438 X_{2}+ \\
0.423820 X_{3}-4,961792 X_{4}
\end{gathered}
$$

Dari hasil persamaan regresi linear data panel tersebut dijelaskan sebagai berikut:

a) Konstanta sebesar -1.952799 artinya apabila semua variabel independen dianggap konstan (bernilai 0) maka nilai perusahaan (PBV) bernilai sebesar -1.952799

b) Struktur Modal (DER) sebesar 0,625761 artinya apabila Debt Equity Ratio (DER) naik sebesar 1 satuan sedangkan variabel lain dianggap konstan maka nilai perusahaan (PBV) akan mengalami kenaikan sebesar 0,625761 satuan.

c) Net Profit Margin (NPM) sebesar 91,32438 artinya apabila Net Profit Margin (NPM) naik sebesar 1 satuan sedangkan variabel lain dianggap konstan maka nilai perusahaan (PBV) akan mengalami kenaikan sebesar 91,32438 satuan.

d) Return On Asset sebesar 0.423820 artinya apabila Return On Asset sebesar 1 satuan sedangkan variabel lain dianggap konstan maka nilai perusahaan (PBV) akan mengalami kenaikan sebesar 0.423820 satuan.

e) Return On Equity sebesar - 4,961792 artinya apabila Return On Equity sebesar 1 satuan sedangkan variabel lain dianggap konstan maka nilai perusahaan (PBV) akan mengalami penurunan sebesar - 4,961792 satuan.

Pembahasan

\section{KESIMPULAN}

Berdasarkan hasil penelitian, maka dapat diambil kesimpulan sebagai berikut:

1. Variabel Struktur Modal (DER), Net Profit Margin (NPM), Return On Asset (ROA) dan Return On Equity (ROE) secara serempak berpengaruh positif terhadap nilai perusahaan.

2. Variabel Struktur modal (DER), Variabel Net Profit Margin (NPM), Variabel Return On Asset (ROA) dan Variabel Return On Asset (ROA) secara parsial berpengaruh positif dan tidak signifikan terhadap nilai perusahaan.

\section{DAFTAR PUSTAKA}

Agus,Sartono.2006. Manajemen Keuangan Teori Dan Aplikasi Edisi Ketiga.Yogyakarta : Bpfe Yogyakarta.

Alexandri, Moh. Benny. 2008. Manajemen Keuangan Bisnis. Cetakan Kesatu. Bandung: Alfabeta.

Amanah Rakhimsyah, Leli Dan Barbara, Gunawan. 2011. Pengaruh Investasi, Keputusan Pendanaan, Kebijakan Deviden Dan Tingkat Suku Bunga Terhadap Nilai Perusahaan. Jurnal Investasi Vol: 7 No 1 Juni. Hal 31-45

Apsari Ayu. (2015) Pengaruh Return On Equity, Net Profit Margin, Debet To Equity Ratio Dan Logterm Debet To Equity Terhadap Price Book Value (Studi Pada Perusahaan Sub Sektor Makanan Dan Minuman Yang Terdaftar Di Bursa Efek Indonesia Periode Tahun 2010-2013.

Bastian, Indra Dan Suhardjono.2006. Akuntansi Perbankan. Edisi1.Jakarta: Salemba Empat.

Brigham, Eugene F., Dan Daves, Philip R. 2004, Intermediate Financial Management :Lanjutan Manajemen Keuangan. Edisi 8 Salemba Empat. Jakarta

Brigham.(2006).Manajemen Keuangan. Jakarta:Erlangga. 
Brigham, Eugene F. Dan Joel F. Houston. 2006. Fundamentals Of Financial Management :Dasar-Dasar Manajemen Keuangan. Buku 1.Edisi 10.Salemba Empat. Jakarta

Chirstanty, Mila. (2009) “Analisis Pengaruh Fundamental Dan Ecnomic Value Added (Eva) Terhadap Return Saham". Tesis Universitas Diponegro. Semarang

Dani Kartiko Kukuh. (2015) Pengaruh Kinerja Keuangan Dan Beta Saham Terhadap Price Book Value Yang Dilakukan Dengan Perusahaan Real Estate Dan Poperti Periode 2004-2006. Skripsi.

Fahrizal. Helmy .(2013) Pengaruh Return On Assets (Roa), Return On Equity (Roe) Dan Investment Opportunity Set (Ios) Terhadap Nilai Perusahaan (Studi Empiris Pada Perusahaan Manufaktur Jenis Consumer Goods Yang Terdaftar Di Bursa Efek Indonesia Periode 20022011).

Febrianti Meiriska. (2012) Faktor-Faktor Yang Mempengaruhi Nilai Perusahaan Pada Industri Pertambangan Di Bursa Efek Indonesia. Jurnal Bisnis Dan Akuntansi. Vol.14,No. 2, Agustus 2012, Hlm.141156.

Fred, Weston, J. Dan Thomas E. Copeland. 1999. Manajemen Keuangan. Edisi 8.Jakarta: Bina Rupa Aksara.

Ghozali, Imam. (2013). Analisis Multivariate Dan Ekonmometrika:Teori, Konsep Dan Aplikasi Dengan. Semarang: Badan Penerbit Universitas Diponegoro

Gultom Robinho Dkk. (2013). Analisis FaktorFaktor Yang Mempengaruh Ini Nilai Perusahaan Pada Perusahaan Farmasi Di Bursa Efek Indonesia. Jurnal Wira Ekonomi Mikroskil.3 (1):51-60

Halim, A. (2007) Akuntansi Sector Public Dan Akuntansi Keuangan Daerah. Edisi Revisi. Salemba Empat: Jakarta

Hanafi, M. Mamduhdan Abdul Halim. "Analisis Laporan Keuangan”, Upp Amp Ypkn, Yogyakarta, 1996.

2008. Manajemen Keuangan. Edisi 1.Yogyakarta : Bpfe.

Harahap, Sofyan Syafri. 2010. Teori Akuntansi Edisi Revisi. Raja Grafindo Persada : Jakarta.

Horne, James C. Van, Dan Machowich, John M. (2005), Fundamentals Of Financial
Management, Prinsip-Prinsip

Manajemen Keuangan Buku I Edisi 12.

Jakarta :Salemba Empat.

Husnan, Suad. 2001. Dasar-Dasar Teori Portofolio Dan Analisis Sekuritas, Edisi Ketiga. Upp Amp Ykpn, Yogyakarta.

Istikhanah. (2015) Judul Penelitian Pengaruh Return On Asset (Roa) Dan Return On Equity (Roe) Terhadap Nilai Perusahaan Pada Perusahaan Yang Listing Di Bursa Efek Indonesia Tahun 2014-2015. Jurnal Ekonomi Vol.14, No.1

Keown (2004) Manajemen Keuangan: PrinsipPrinsip Dan Aplikasi, Edisi Kesembilan, Jakarta : Pt Indeks.

Kasmir. 2012. Analisis Laporan Keuangan, Jakarta: Pt. Raja Grafindo Persada.

Krik, J Dan Miller, M. L., 1986 Reliability And Validity In Qualitative Research,Beverly Hills, Ca, Sage Publications

Mardiyanto, Handoyo. 2009. Intisari Manajemen Keuangan. Jakarta: Pt Grasindo.

Muhammad, Eldwin.(2016) Analisis Return On Asset (Roa), Current Ratio (Cr), Debt To Equity Ratio (Der), Net Profit Margin (Npm) Terhadap Nilai Perusahaan (Studi Kasus Pada Perusahaan Manufaktur Sektor Consumer Goods Yang Tercatat Di Bursa Efek Indonesia Periode 20112014).

Marjun, M. (2019). Pengaruh Di Mensi Dimensi Kualitas Layanan Terhadap Kepuasan Pasien Rawat Inap Bpjs Kesehatan Center Rumah Sakit Umum Daerah Anutapura. Jurnal Ekonomi Trend, 7(1), 12-26.

Https://Doi.Org/10.31970/Trend.V7i1.17 0

Mursidah, Nurfadilah.(2011). "Analisis Pengaruh Earning Per Share, Debt To Equity Ratio Dan Return On Equity Terhada Harga Saham Pt Unilever Indonesia Tbk", Jurnal Stie Muhamadyah Samarinda, Vol.12 No.1, 2011

Puspitasari. (2015) Dengan Judul Penelitian Pengaruh Kinerja Keuangan Terhadap Nilai Perusahaan (Studi Emperis Di Perusahaan Food And Beverages Yang Terdaftar Di Bei Tahun 2011-2013). Jurnal Ekonomi Dan Bisnisvol.14,No.1, November. 
Prananti.(2013) Dengan Judul Analisis Pengaruh

Rasio Profitabilitas Terhadap Nilai Perusahaan Manufaktur Sub-Sektor Otomotif Dan Komponen Di Bursa Efek Indonesia. Jurnal Administrasi Bisnis Vol.38, No.2, September.

Prihadi, Toto. 2008. Analisis Rasio Keuangan, Ppm Manajemen, Jakarta

Prisilia (2013). Pengaruh Struktur Modal, Profitabilitas, Dan Kepemilikan Manajerial Terhadap Nilai Perusahaan Pada Perusahaan Consumer Goods Yang Terdaftar Di Bei Periode 2008-2012.

Rinanti 2008. Manajemen Keuangan Bisnis. Cetakan Kesatu. Bandung: Alfabeta, Bandung

Riyanto, Bambang.(2001). Dasar-Dasar Pembelanjaan Perusahaan.Yogyakarta : Bpie

Riyadi, Selamet. 2006. Banking Assets And Liability Management. Edisi 3.Jakarta: Lembaga Penerbit Fakultas Ekonomi Universitas Indonesia.

Robert Ang. 1997. Buku Pintar Pasar Modal Indonesia. Jakarta. Mediasoft Indonesia.

Sartono, R. A.(2001). Manajemen Keuangan Teori Dan Aplikasi. Edisi4.Yogyakarta: Bpfe.

Salvatore, Dominick. (2005). Ekonomi Manajerial Dalam Perekonomian Global. Salemba Empat : Jakarta.

Sawir, Agnes. 2009 Analisis Kinerja Keuangan Dan Perencanaan Keuangan Perusahaan, Jakarta : Pt. Gramedia Pustaka Utama.

Sujoko Dan U. Soebiantoro (2007). Pengaruh Struktur Kepemilakan Saham, Laverage, Faktor Inter Dan Ekstern Terhadap Nilai Perusahaan. Jurnal Manajemen Dan Kewirausahaan. Vol.9 No.1.Maret.

Sugiono. (2006). Metode Penelitian Bisnis. Bandung: Alfabeta

Sutrisno. (2001)Manajemen Keuangan”, Ekonesia, Yogyakarta, 2001.

. (1999) Metode Penelitian Bisnis. Edisi 1. Bandung Cv Alfa Beta.

Sugiyono. 2011. Metode Penelitian Kuantitatif, Kualitatif Dan $R \& D$. Alfabeta, Bandung.

Sugiyono. 2002. Metode Penelitian Bisinis, Bandung: Cv. Alfabeta
Tambunan, Andy. 2007. Menilai Harga Wajar Saham. Cetakan Kedua. Jakarta: Pt Grasindo.

Tetelepta I.E. 2011. Pengaruh Kinerja Keuangan Terhadap Nilai Perusahaan Pada Perusahaan Manufaktur Yang Terdaftar Di Bursa Efek Indonesia. Skripsi Sekolah Tinggi Ekonomi Perbanas. Surabaya

Umar A, M. (2019). Strategi Pemasaran Dalam Upaya Peningkatkan Volume Penjualan Perusahaan Comforta Palu. Jurnal Ekonomi Trend, 7(1), 27-40. Https://Doi.Org/10.31970/Trend.V7i1.17 1

Weston, J.F. And T.E. Copeland.(1995). Manajemen Keuangan, Jilid Kesatu, Alih Bahasa Oleh A. Jaka Wasana Dan Kirbrandoko. Jakarta: Bina Rupa Aksara.(1997). Manajemen Keuangan, Jilidkedua, Alih Bahasa Oleh A. Jaka Wasana Dan Kirbrandoko. Jakarta: Bina Rupa Aksara.

Widarjono, A. 2013. Ekonometrika Teori Dan Aplikasi Untuk Ekonomi Dan Bisnis. Edisi Ketiga. Upp Stim Ykpn. Yogyakarta.

Www.Idx.Co.Id

Www.Saham Ok.Com. 